\title{
幼児の心房中隔欠損閉鎖術における美容上有利な到達法 一低位正中皮膚小切開下胸骨全長切開一
}

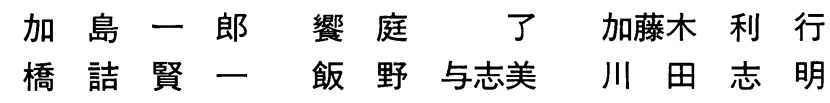

\begin{abstract}
近年, 小児心蔵手術において, 手術の内容や成績といった本質論のほかに, 美容的な工夫が社会的な 需要として高まってきている. 当施設では 1998 年 5 月から 1999 年 4 月までの 1 年間に 6 人の心房中 隔欠損の患者（2６歳, 平均体重 $15.8 \pm 1.3 \mathrm{~kg}$ ） に対し乳頭位から剣状突起直上までの皮膚小切開 $(4.2 \sim 5.8 \mathrm{~cm}$, 平均 $4.9 \pm 0.3 \mathrm{~cm})$ と, 胸骨全長切開による到達法で，傊孔閉鎖術を施行した。 こ の方法で手術を施行した患者群を体重をマッチングさせた従来の到達法で手術した患者群と比較した ところ, 手術時間, 体外循環時間, 大動脈遮断時間および術後の賓血の進行度に有意差を認めなかっ た．創感染や皮下血腫を含む手術創のトラブルはなかった。この方法は胸骨を全長にわたって切開し ているので緊急時の対応にも優れていると考えられる. 美容上の見地から, 本到達方法は十分安全で 満足の得られる手術方法と考えられる. 日心外会誌 29 巻 4 号：225-228 $(2000)$
\end{abstract}

Keywords：皮䖉小切開, 低位正中位, 胸骨全長切開, 心房中隔欠損

\section{Lower Mid-line Skin Incision with Full Sternotomy as an Approach for Pediatric Atrial Septal Defect Repair}

Ichiro Kashima, Ryo Aeba, Toshiyuki Katogi, Kenichi Hashizume, Yoshimi Iino and Shiaki Kawada (Department of Surgery, Keio University School of Medicine, Tokyo, Japan)

Recently, the demand for better cosmetic outcomes in pediatric cardiovascular operations has been growing. Between May 1998 and April 1999, six children aged 2 to 6 years with an ostium secundum type of atrial septal defect underwent reparative operations that used an approach consisting of a lower mid-line skin incision with full sternotomy. A $4.2-5.8 \mathrm{~cm}$ vertical skin incision (mean, $4.9 \pm 0.3 \mathrm{~cm}$ ) was made between the level of the nipple and the xyphoid process. Comparison between this series and a group of weight-matched patients who underwent conventional operations revealed no significant differences in operation time $(166.0 \pm 12.0 \mathrm{vs} .147 \pm 8.4$ $\mathrm{min})$, cardiopulmonary bypass time $(33.2 \pm 4.0 \mathrm{vs}$. $32.2 \pm 2.4 \mathrm{~min})$, aortic cross-clamp time $(13.8 \pm 2.3$ vs. $12.3 \pm 1.3 \mathrm{~min})$, or the reduction in the hemoglobin concentration in blood on the first postoperative day $(1.7 \pm 0.3 \mathrm{vs} .2 .9 \pm 0.6 \mathrm{~g} / \mathrm{dl})$. The surgical wound was not associated with any complications in our series, including wound infection or subcutaneous hematoma. Our technique appears to be safe and provide satisfactory cosmetic outcome. Jpn. J. Cardiovasc. Surg. $29: 225-228$ (2000)

胸骨正中切開は心臓手術においては最も一般的 な到達法であるが，小児心臟手術の領域でも，心 房中隔欠損 (ASD) や心室中隔欠損などといっ た手術手技が単純で手術成績が安定した現在で は，手術内容もさることながら手術創の美容的な 要素の改善も社会が要求する時代になっている. 美容的要素を重視した手術方法としては右開胸に よる到達法 ${ }^{1)}$, 乳房下切開による到達法 ${ }^{21}$, 切開

1999 年 6 月 17 日受付， 1999 年 10 月 15 日採用 慶應義塾大学外科 T 160-8582 東京都新宿区信濃町 35
線を短縮した胸骨部分正中切開による到達法 3 5) など報告は散見される。今回われわれは，ASD の症例に対し, 皮膚切開を乳頭位から剣状突起直 上までとし，胸骨正中切開は全長にわたって行う 到達法にて手術を施行し，手技的にも美容的にも 満足のいく結果を得たので報告する.

\section{患者および手術方法}

\section{患 者}

1998 年 5 月から 1999 年 4 月までの 1 年間に 6 人の幼児に皮膚小切開による方法で二次孔型 
表 1 皮膚小切開法で手術を施行した心房中隔欠損症例(小切開群)

\begin{tabular}{ccccccccccc}
\hline Case & $\begin{array}{c}\text { Age } \\
(\text { years })\end{array}$ & $\begin{array}{c}\text { Weight } \\
(\mathrm{kg})\end{array}$ & $\begin{array}{c}\text { ope-T } \\
(\mathrm{min})\end{array}$ & $\begin{array}{c}\text { AoX-T } \\
(\mathrm{min})\end{array}$ & $\begin{array}{c}\text { CPB-T } \\
(\mathrm{min})\end{array}$ & $\begin{array}{c}\text { pre Hb } \\
(\mathrm{g} / \mathrm{dl})\end{array}$ & $\begin{array}{c}\text { POD Hb } \\
(\mathrm{g} / \mathrm{dl})\end{array}$ & $\begin{array}{c}\text { R-Hb } \\
(\mathrm{g} / \mathrm{dl})\end{array}$ & $\begin{array}{c}\text { Portion } \\
\text { of A }\end{array}$ & $\begin{array}{c}\text { Wound size } \\
(\mathrm{cm})\end{array}$ \\
\hline 1 & $2(\mathrm{~F})$ & 10.1 & 120 & 9 & 23 & 13.2 & 10.7 & 2.5 & Ao & 4.2 \\
2 & $3(\mathrm{~F})$ & 17.5 & 162 & 13 & 32 & 13.1 & 10.9 & 2.2 & $\mathrm{f}$ & 5.8 \\
3 & $6(\mathrm{~F})$ & 15.4 & 185 & 24 & 51 & 12.7 & 11.7 & 1.0 & $\mathrm{f}$ & 4.3 \\
4 & $4(\mathrm{~F})$ & 15.3 & 180 & 15 & 37 & 13.0 & 12.5 & 0.5 & $\mathrm{f}$ & 4.8 \\
5 & $6(\mathrm{~F})$ & 20.0 & 202 & 13 & 28 & 13.0 & 10.8 & 2.2 & $\mathrm{f}$ & 4.7 \\
6 & $5(\mathrm{~F})$ & 16.5 & 147 & 9 & 28 & 13.6 & 12.1 & 1.5 & $\mathrm{f}$ & 5.8 \\
\hline
\end{tabular}

$\mathrm{F}$ : female, ope- $\mathrm{T}$ : operation time, $\mathrm{CPB}-\mathrm{T}$ : cardiopulmonary bypass time, pre $\mathrm{Hb}$ : pre-operative hemoglobin concentration, $\mathrm{R}-\mathrm{Hb}$ : reduction in the hemoglobin concentration, Portion of $\mathrm{A}$ : portion of arterial cannulation, Ao: aorta, $\mathrm{f}$ : femoral artery.

表 2 従来の切開法で手術を施行した心房中隔欠損症例 (対照群)

\begin{tabular}{ccccccccccc}
\hline Case & $\begin{array}{c}\text { Age } \\
\text { (years) }\end{array}$ & $\begin{array}{c}\text { Weight } \\
(\mathrm{kg})\end{array}$ & $\begin{array}{c}\text { ope-T } \\
(\mathrm{min})\end{array}$ & $\begin{array}{c}\text { AoX-T } \\
(\mathrm{min})\end{array}$ & $\begin{array}{c}\text { CPB-T } \\
(\mathrm{min})\end{array}$ & $\begin{array}{c}\text { pre Hb } \\
(\mathrm{g} / \mathrm{dl})\end{array}$ & $\begin{array}{c}\text { POD Hb } \\
(\mathrm{g} / \mathrm{dl})\end{array}$ & $\begin{array}{c}\text { R-Hb } \\
(\mathrm{g} / \mathrm{dl})\end{array}$ & $\begin{array}{c}\text { Portion } \\
\text { of A }\end{array}$ & Wound size \\
\hline 1 & $4(\mathrm{~F})$ & 14.2 & 177 & 10 & 35 & 13.5 & 9.8 & 3.7 & Ao & full \\
2 & $4(\mathrm{M})$ & 13.7 & 120 & 13 & 28 & 13.3 & 11.0 & 2.3 & Ao & full \\
3 & $5(\mathrm{~F})$ & 13.2 & 162 & 17 & 39 & 13.3 & 7.9 & 5.4 & Ao & full \\
4 & $4(\mathrm{~F})$ & 16.0 & 154 & 15 & 38 & 14.2 & 12.4 & 1.8 & Ao & full \\
5 & $4(\mathrm{M})$ & 14.4 & 133 & 10 & 28 & 12.2 & 10.2 & 2.0 & Ao & full \\
6 & $5(\mathrm{M})$ & 15.2 & 140 & 9 & 25 & 13.3 & 11.3 & 2.0 & Ao & full \\
\hline
\end{tabular}

$\mathrm{M}$ : male, $\mathrm{F}$ : female, ope-T : operation time, $\mathrm{CPB}-\mathrm{T}$ : cardiopulmonary bypass time, pre $\mathrm{Hb}$ : pre-operative hemoglobin concentration, $\mathrm{R}-\mathrm{Hb}$ : reduction in the hemoglobin concentration, Portion of $\mathrm{A}$ : portion of arterial cannulation, Ao: aorta, full : full skin incision.

ASD の閉鎖術を施行した。年齢は 2〜 6 歳で，体 重は $10.1 〜 20.0 \mathrm{~kg}$ (平均 $15.8 \pm 1.3 \mathrm{~kg}$ ) であっ た (小切開群) (表 1)。いつぽう，1996 年 12 月か ら 1997 年 11 月までの 1 年間に従来の到達法で二 次孔型 ASD の閉鎖術を施行した患者のうち，体 重を一致させた 6 人の幼児を対照群とした（表 2).

\section{皮膚小切開群の手術方法}

皮膚切開は乳頭位から剣状突起直上までとした $(4.2 \sim 5.8 \mathrm{~cm}$, 平均 $4.9 \pm 0.3 \mathrm{~cm})$. 皮下組織を 大胸筋前筋膜下にて胸骨前面加ら十分剥離をする ことにより皮弁を作製し，胸骨柄上縁から剣状突 起下緑まで露出させた。胸骨前後面を十分剝離し たのち, 脸骨の下縁から上方に向かって, 幅狭の ブレードのついた水平オシレーティング胸骨鋸を 用いて完全に胸骨正中切開した，胸骨上縁部は胸 骨鋸の刃が届かないこともあるため，その場合に
は長骨尖刀で追加切断した．胸骨およびその周辺 からの出血は Argon Beam Coagulator を用いて 止血した. その後は開胸器を入れ, 通常どおり心 膜を切開した。心膜の牽引系は頭側では皮膚切開 創とは別に直接皮膚を貫くようにし，皮弁を肩甲 骨鈎にてつり上げることで良好な視野を確保し た.上行大動脈, 上大静脈および下大静脈のテー ピングは通常どおり可能であり, 脱血カニューレ の挿入も通常どおり行えた。 上行大動脈送血はこ の視野からは困難であることが多いため，1例を 除き左鼠径部を皮膚媰にそって約 $1.5 \mathrm{~cm}$ 長の斜 切開を行い大腿動脈を露出させ, そこから送血力 ニューレを挿入した。大動脈遮断は通常どおり可 能であった. 心内修復終了後, 胸骨は第 2 肋骨レ ベルから胸骨体下部までワイヤーにて通常どおり の方法で閉鎖可能であった. 皮膚は埋没縫合にて 閉鎖した。 


\section{統 計 処 理}

小切開群と対照群を手術時間, 体外循環時間, 大動脈遮断時間, 術後 1 日目における血中へモグ ロビン濃度の減少度について比較した。また，術 後 9 日から 26 日目までの間に術後心エコー検査 による評価を行った。統計処理は $t$ 検定で行い, $p<0.05$ の場合を有意とした。

\section{結果}

今回の手術方法で手術死亡はなかった。手術時 間は皮膚小切開群では $166.0 \pm 12.0$ 分対対照群 $147 \pm 8.4$ 分で有意差はなかった。体外循環時間 は皮膚小切開群 $33.2 \pm 4.0$ 分対対照群 $32.2 \pm 2.4$ 分で有意差はなかった。大動脈遮断時間は皮膚小 切開群 $13.8 \pm 2.3$ 分対対照群 $12.3 \pm 1.3$ 分で有意 差はなかった。術後 1 日目の血中へモグロビン濃 度の減少度は皮膚小切開群 $1.7 \pm 0.3 \mathrm{~g} / \mathrm{dl}$ 対対照 群 $2.9 \pm 0.6 \mathrm{~g} / \mathrm{dl}$ で有意差はなかった。なお，同 種輸血をした症例は両群ともになかった。皮下血 腫, 創感染，胸骨感染を含む，手術創に関する合 併症はなかった。両群とも術後疼痛の訴えはほと んどなく，鎮痛剤を必要とした幼児はいなかっ た。術後心エコー検查では残存 ASD はなく,ま た術後の心囊液貯留の発現頻度は少量の貯留も含 めて, 小切開群 2 例, 対照群 1 例であった。抗瘶 痕剤はとくに使用しなかったが, 術後 $2 \sim 13$ 力月 の経過観察では通常切開と同様, 創幅が $7 \mathrm{~mm}$ を越える皮膚のケロイド形成はなかった。また， 胸郭の変形もみられなかった。

\section{考察}

近年小児心臓外科領域でも ASDのようなほぼ 手術近接死の可能性のないような手術においては 手術創の縮小といった美容上の問題にも外科医が 注意を払わなければならなくなってきている。と くに女児にとっては将来思春期を迎えるため，傷 が小さくきれいであるということは高齢者あるい は男性と比較してもより重要な問題といえるかも しれない。以前より，ことにASDの手術におい ては手術創の美容上の工夫はされており，たとえ ば乳房下縁にそった切開線は比較的早期から報告 がされている。しかし乳房の未発達な女児におい
ては乳腺の発達に個人差があるため, その切開線 の位置を決めるのは比較的困難に思われる。ま た, 側方開胸の場合, 術後の疼痛の訴えが多く, 横隔膜神経麻痺の発生も $4.1 \%$ で胸骨正中切開の ほぼ 2 倍であるとする報告もある6)．以上より幼 児においては側方開胸の利点については疑問が残 る. 正中切開法は数多くの利点があるが, 患者の 最大の関心はその手術創が日常生活で見栄えがよ いということである。美容上の見地からすると手 術創を小さくすることはもちろん重要であるが, その位置が首からなるべく離れているほうが優れ ている。したがってわれわれは手術創が乳頭位置 より下方になることに重点をおいた。手術創を小 さくすることは視野の縮小のため当然手術は難し くなるが，今回われわれの方法では胸骨は全長に わたって切断するため比較的好視野が得られた。 また, 胸骨全長切開のため, 緊急時の通常切開へ の移行も迅速かつ簡単に行える.今回のシリーズ では通常の到達法の手術と比較して, 手術時間, 体外循環時間, 大動脈遮断時間, 術後貧血の程度 に有意差は認められなかった。したがって，特殊 な器械や消耗材を用いることもなく, 手術室の人

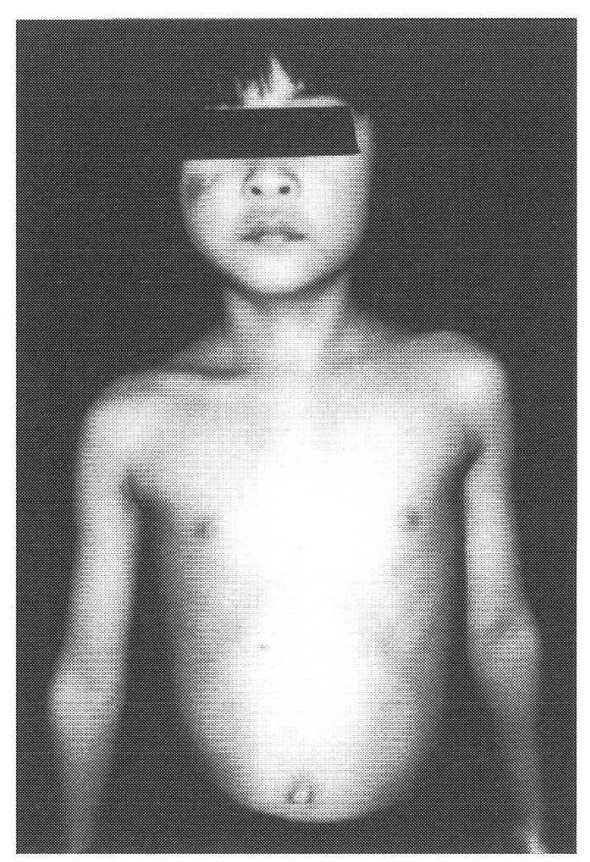

図 1 皮膚小切開法で手術を施行された症例の術後 3 カ月目の手術創 
的資源も新たに発生しないという意味で十分実用 性のある方法と考えられる。

今回のシリーズでは皮下血腫や創感染といった 傷に関するトラブルはなかった。 また, 皮膚小切 開法では，通常切開のように第 1 肋間レベルから のワイヤー固定は技術的に困難なため行わなかっ たが, 胸郭の変形は見られなかった。坚の場合 は成人に比へ，胸骨に加重する絶対的な力が小さ いためと骨折治癒力が強いためと考えられる. 皮 膚小切開が低侵襲手術であるか否かは議論の余地 はあるが，少なくとも美容上の見地からすると， われわれの方法は十分に満足のいく方法であり， かつ安全性に優れていると考える (図 1).

\section{文献}

1) Rosengart, T.K. and Stark, J.F.: Repair of atrial septal defect through a right thoracotomy. Ann. Thorac. Surg. 55 : 1138-1140, 1993.
2) Bédard, P., Keon, W. J., Brais, M.P. et al. : Submammary skin incision as a cosmetic approach to median sternotomy. Ann. Thorac. Surg. 41 : 339-341, 1986.

3) Gundry, S. R., Shattuck, O. H., Razzouk, A. J. et al.: Facile minimally invasive cardiac surgery via ministernotomy. Ann. Thorac. Surg. 65 : 1100-1104, 1998.

4) Komai, H., Naito, Y., Fujiwara, K. et al. : Lower mid-line skin incision and minimal sternotomy - a more cosmetic challenge for pediatric cardiac surgery. Cardiol. Young 6 : 76-79, 1996.

5) Wilson, W. R., Ilbawi, M. N., DeLeon, S. Y. et al.: Partial median sternotomy for repair of heart defects: A cosmetic approach. Ann. Thorac. Surg. 54 : 892-893, 1992.

6) Watanabe, T., Trusler, G. A., Williams, W. G. et al.: Phrenic nerve paralysis after pediatric cardiac surgery-retrospective study of 125 cases-. J. Thorac. Cardiovasc. Surg. 94 : 383388, 1987. 